\title{
Enhancing the Administration of an Early Intervention Educational Programme Through Technology; Exploring Usage, Acceptance and Attitudes
}

\author{
Grainne Kent ${ }^{* a}$, Angeline Traynor ${ }^{\mathrm{a}}$, Kate Darmody ${ }^{\mathrm{a}}$ and Tess O'Leary ${ }^{\mathrm{a}}$ \\ ${ }^{a}$ National College of Ireland
}

(Received March 2019; final version received July 2019)

\begin{abstract}
The study aimed to investigate information technology use, attitudes and acceptance before and after the introduction of technology-based work practices in a community-based educational initiative. A convenience sample of Home Visitors was recruited, and a composite survey was used to collect data on participant use, attitudes and acceptance of technology prior to and following the implementation of the new system. Correlations were used to explore the relationship between usage, acceptance and attitudes while Wilcoxon tests were used to explore differences in participants' usage, attitudes and acceptance following the implementation of the system. A total of 21 Home Visitors completed the survey at baseline and again at one academic year follow-up. Several factors were identified as potentially important in relation to Home Visitor use of technology which included aspects of both attitude (positive attitude and anxiety dependence) and acceptance (needs satisfaction and use intention). Results of the Wilcoxon test revealed little change in participant use of technology, which was high from the outset. Anxiety dependence, a component of attitude, was significantly greater at follow-up in comparison with baseline levels. No significant differences were observed in pre-post self-
\end{abstract}

\footnotetext{
*Corresponding author. Email: grainne.kent@ncirl.ie Irish Journal of Technology Enhanced Learning Ireland, 2020. (C) 2020 Kent, G. The Irish Journal of Technology Enhanced Learning Ireland is the journal of the Irish Learning Technology Association, an Irish-based professional and scholarly society and membership organization. (CRO\# 520231) http://www.ilta.ie/ . This is an Open Access article distributed under the terms of the Creative Commons Attribution 4.0 International License (http://creativecommons.org/licenses/by/4.0), allowing third parties to copy and redistribute the material in any medium or format and to remix, transform, and build upon the material for any purpose, even commercially, provided the original work is properly cited and states its license.
} 
reported acceptance of technology. These findings serve as a guide for community-based organisations considering a move toward technology-mediated work practices.

\section{Introduction}

In delivering educational programmes and interventions, technological advancements bring welcomed supports. Through technology adoption organisations can improve service delivery through increased access to information and materials, improved internal and external communication and more time efficient work practices (Hoeven, van Zoonen \& Fonner, 2016). Technology adoption, in this study, refers to the introduction of technology designed to collect, and store data related to the various programmes delivered in one such community based educational programme, the Early Learning Initiative (ELI).

Following a decade in operation the ELI recognised the need to improve their infrastructure through a move towards technology-based practices. Their flagship programme, the Parent Child Home Programme, was selected as the pilot programme to begin the transition towards technology adoption. This programme involves trained Home Visitors visiting the homes of children, between the ages of 18 and 36 months, and their parents in the area twice weekly. The aim is to support parents to develop the skills to support their child's learning and development (Share et al. 2011). Record keeping is a key part of the role of a Home Visitor, with daily data recorded allowing an overview of attendance, engagement, progress and outcomes. While these records have been traditionally paper based, moving towards technology-based record keeping has potential advantages to programme delivery. This adaption involved programme staff being given a smart phone to use, with a Customer Relations Management System being the tool for recording this data. In order to support the implementation of this system, all team members participated in five days training on how to use this new system.

In generating an understanding of the factors which affect technology adoption in the work place, several different models have been proposed (Taherdoost, 2018). Among these the Technology Acceptance Model (TAM; Davis, 1989) stands out because it is an encompassing and widely researched tool used across disciplines to explain the factors that affect adult acceptance, attitudes and subsequent usage of technology (Scherer, Siddiq \& Tondeur, 2019).

According to the TAM (Davis, 1989), when users are presented with a new technology, their decision to use it is influenced by several factors. These factors include perceived usefulness, ease of use (both aspects of acceptance) and the attitude of the user, all of which are considered predictors of the outcome variable, the intention to use technology and the use of technology (Bautista, Rosenthal, Lin \& Theng, 2018). Essentially the model suggests that if an individual perceives a type of technology to be useful and easy to use, they will have a more positive attitude towards technology which will affect their intention and subsequent use of technology.

Since its development in 1989, several extensions of the TAM have been proposed in response to criticisms of the model (Taherdoost, 2018). Particularly, its lack of attention to external factors which resulted in extensions of the TAM to incorporate factors such as self-efficacy, social norms and voluntariness, and cognitive factors relating to job relevance and output quality. Of note however, in subsequent adaptions to the TAM model, the attitude construct was removed due to a lack of empirical support (Guo \& Zhou, 2016). 
While more recent adaptions of the TAM model have removed the construct of attitude, recently researchers have argued that the role of attitude should be re-considered, given the important role of attitude in general behaviour change. For example, Guo and Zhou (2016) suggest that previous research exploring the role of attitude focused solely on attitude as a unidimensional concept rather than bi-dimensional concept. In their research they explored attitude from a bi-dimensional aspect and found evidence of the role of attitude in behavioural intention. With evidence of more negative attitudes towards technology developing during later stages of adulthood (Lee et al. 2019), it is important to explore the role of positive and negative attitudes towards technology in predicting technology adaption. Furthermore, an aspect of attitude which may also be of interest to explore is attitudes that reflect anxiety and dependence on technology given the evidence emerging of the negative impact of not having access to technology on our anxiety levels (Cheever, Rosen, Carrier, \& Chavez, 2014).

Therefore, the primary aim of the current research is to explore Home Visitors' attitudes, acceptance and usage of technology. Secondly, the study aims to explore in what way, if any, the move towards technology-based work practices may impact on Home Visitors' attitudes and acceptance of technology.

\section{Methods}

Sample: Participants were 21 adult ( $>18$ years) Home Visitors who were employed by the Early Learning Initiative to facilitate the delivery of the Parent Child Home Programme. All participants were female, and ages ranged from 28 to 54, with the average age being 40 . Participant level of education is described primarily as second level education and non-degree qualification. No participants had a third level qualification at the time of data collection. Due to concerns with participant confidentiality, the researchers were provided with the overall sample demographics however they were not permitted have access to individual's personal information.

Ethics: This study was approved by the National College of Ireland Research Ethics Committee. Due to the power relationship that exits between employees and management, Home Visitors were repeatedly, reassured their contribution to this research would have no impact of their employment. They were asked to participate in the study by the Researchers and there was no involvement of the management team.

Design and Procedure: A before and after, non-experimental design was used. Baseline data was collected at the start of the academic year prior to commencing to use the new system. At the end of the academic year, following 9 months of technology implementation, post intervention data was collected. Questionnaires that presented with $20 \%$ or more, missing data were discarded.

Measures: The survey used was developed using items from several different sources with some modifications to suit the study context to measure the TAM constructs (see appendix 1).

- Use of technology was measured using the Technology Survey-Adapted (Marston, Kroll, Fink, de Rosario, \& Gschwind, 2016). In order to suit the context within which the research was being conducted, the word computers were changed to computer/tablet/smartphone. The Technology Survey asks participants to report on 
their use of a computer/tablet/smartphone with the following main variables used: Experience with technology (month and years), Frequency of use (days, weeks, months), Frequency of use (hours per week) and Use of technology (activities done using technology).

- Attitudes toward technology were measured using the Media and Technology Usage and Attitudes Scale (Rosen et al. 2013). This measure asks participants to rate the extent to which they agree or disagree with several statements examining attitudes based on a 5 point Likert scale (5-strongly agree, 4- agree, 3-neither agree nor disagree, 2-disagree, 1- strongly disagree). The validity of the attitude measure was evident by the authors with $66 \%$ of the variance being accounted for while good reliability was evident with a Cronbach alpha score of .84. Three of the four factors identified by Rosen et al. were used in this study: Positive Attitude (seeing technology as important/beneficial), Negative Attitude (seeing technology as an interference/ inconvenience) and Anxiety Dependence (dependence on technology and anxiety when no access to technology). Higher scores on each of these factors indicated a more positive attitude towards technology, a more negative attitude towards technology and more anxiety dependence.

- Technology was measured using an adapted version of the Older Adults' Information Technology Acceptance Questionnaire (Wang, Rau, \& Salvendy, 2011). The validity of this measure has been shown by the authors with these four factors accounting for $63.4 \%$ of the overall variability which good reliability has been evidenced with overall internal consistency of .896. The four factors identified by Wang et al. were therefore used for this study: Needs satisfaction, Public acceptance, Use Intention and Support Availability.

Statistical analysis: Was conducted using SPSS 25.0 (SPSS IBM). Survey data was scored and summed to provide a total number, mean or percentage. 


\section{Results and Discussion}

Descriptive Statistics of Experience with Technology, Frequency of Using Technology and Use Pre and Post

As can be seen in Tables 1-3, Descriptive Statistics on usage revealed that all participants had experience with technology prior to completing training.

Table 1: Table of Experience with Technology

\begin{tabular}{|l|l|l|}
\hline Experience Length & Number Pre & Number Post \\
\hline More than 1 year & 16 & 18 \\
\hline More than 6 months & 1 & 3 \\
\hline More than 2 months & 2 & - \\
\hline 1 month or less & 2 & - \\
\hline
\end{tabular}

Table 2: Frequency of Using Technology (hours)

\begin{tabular}{|l|l|l|}
\hline Hours & Pre & Post \\
\hline $0-1$ & 8 & 1 \\
\hline Less than 5 hours & 4 & 8 \\
\hline $6-10$ hours & 2 & 2 \\
\hline $10+$ hours & 7 & 9 \\
\hline
\end{tabular}

Table 3: Table of Technology Use Pre and Post

\begin{tabular}{|l|l|l|}
\hline Technology Use & Number Pre $(\mathrm{N}=21)$ & Number Post $(\mathrm{N}=21)$ \\
\hline Email & 17 & 17 \\
\hline Social Media & 13 & 13 \\
\hline Internet Checking Facts & 12 & 14 \\
\hline Internet Banking & 9 & 11 \\
\hline Internet Shopping & 9 & 7 \\
\hline Word Processing & 7 & 8 \\
\hline Playing Games & 4 & 4 \\
\hline Drawing & 1 & 0 \\
\hline Data Base & 1 & 1 \\
\hline Other & 4 & 10 \\
\hline
\end{tabular}




\section{Kent et al}

\section{Research Questions}

A number of Spearman Rank Order Correlations were conducted in order explore Home Visitors' attitudes, acceptance and usage of technology. The use of this analysis with the current sample was deemed justifiable due to the violation of assumptions for the use of Pearson's correlation. However, the results should be interpreted with caution due to the small sample size and the monotonic relationship being met to only some extent.

The results of these correlations are presented below, along with a brief interpretation of the meanings. Time 1 (T1) refers to the pre-implementation data while Time 2 (T2) refers to follow up assessments.

\begin{tabular}{|c|c|c|c|c|c|c|c|}
\hline & & 1 & 2 & 3 & 4 & 5 & 6 \\
\hline 1 & $\begin{array}{l}\text { T1 How long have you used a } \\
\text { computer/tablet/smartphone? }\end{array}$ & & & & & & \\
\hline 2 & $\begin{array}{l}\text { T2 How long have you used a } \\
\text { computer/tablet/smartphone? }\end{array}$ & 0.127 & & & & & \\
\hline 3 & $\begin{array}{l}\text { T1 How frequently do you use a } \\
\text { computer/tablet/ } \\
\text { smartphone? }\end{array}$ & $.809^{* *}$ & 0.160 & & & & \\
\hline 4 & $\begin{array}{l}\text { T2 How frequently do you use a } \\
\text { computer/tablet/ } \\
\text { smartphone? }\end{array}$ & $\overline{-}-180$ & $-\overline{0} \cdot 181$ & -0.215 & & & \\
\hline 5 & $\begin{array}{l}\text { T1 How many hours a week do you use a } \\
\text { computer/tablet/ smartphone? }\end{array}$ & 0.249 & 0.199 & 0.446 & -0.328 & & \\
\hline 6 & $\begin{array}{l}\text { T2 How many hours a week do you use a } \\
\text { computer/tablet/ smartphone? }\end{array}$ & 0.152 & 0.153 & 0.324 & $.528^{*}$ & 0.072 & \\
\hline 7 & T1 Positive Attitude & 0.254 & 0.350 & 0.438 & 0.090 & $.504^{*}$ & 0.378 \\
\hline 8 & T2 Positive Attitude & $\overline{-}-128$ & $\overline{-} 0.035$ & -0.248 & 0.083 & -0.430 & 0.232 \\
\hline 9 & T1 Negative Attitude & 0.071 & 0.231 & -0.072 & -0.090 & -0.022 & $-\overline{0} \cdot 182$ \\
\hline 10 & T2 Negative Attitude & 0.298 & 0.320 & 0.291 & 0.169 & 0.221 & 0.306 \\
\hline 11 & T1 Anxiety Dependence & $.620^{*}$ & 0.298 & $.766^{* *}$ & 0.129 & 0.320 & $.509^{*}$ \\
\hline 12 & T2 Anxiety Dependence & 0.133 & 0.179 & -0.128 & 0.432 & $-.673^{* *}$ & 0.200 \\
\hline
\end{tabular}

Table 4: Do participants' experience and usage of technology relate to their attitudes towards technology?

The relationship between experience and frequency of using technology and the level of anxiety dependence suggests that greater use of technology among employees is associated with greater anxiety at lack of access to technology. This is consistent with the research which found that university students with a high level of daily use of technology devices are more likely to experience increasing levels of anxiety when separated (Cheever, Rosen, Carrier \& Chavez, 2014). It is interesting to note that the relationship between use of technology (hours) at baseline and anxiety dependence at $\mathrm{T} 2$ is a negative relationship, suggesting that the more 
frequently we used technology before a move towards technology mediated work practices, the less anxious we are about having access to technology following the implementation. Furthermore, the relationship between hours of use at baseline and positive attitude towards technology suggests that the more we use technology the more positive we are about it.

Table 5: Do participants' experience and usage of technology relate to their acceptance of technology?

\begin{tabular}{|c|c|c|c|c|c|c|c|}
\hline & & 1 & 2 & 3 & 4 & 5 & 6 \\
\hline 1 & $\begin{array}{l}\text { T1 How long have you used a } \\
\text { computer/tablet/smartphone? }\end{array}$ & & & & & & \\
\hline 2 & $\begin{array}{l}\text { T2 How long have you used a } \\
\text { computer/tablet/smartphone? }\end{array}$ & 0.127 & & & & & \\
\hline 3 & $\begin{array}{l}\text { T1 How frequently do you use a } \\
\text { computer/tablet/smartphone? }\end{array}$ & $.809^{* * *}$ & 0.160 & & & & \\
\hline 4 & $\begin{array}{l}\text { T2 How frequently do you use a } \\
\text { computer/tablet/smartphone? }\end{array}$ & -0.180 & $\overline{-}-181$ & $\overline{-}-215$ & & & \\
\hline 5 & $\begin{array}{l}\text { T1 How many hours a week do you use a } \\
\text { computer/tablet/smartphone? }\end{array}$ & 0.249 & 0.199 & 0.446 & -0.328 & & \\
\hline 6 & $\begin{array}{l}\text { T2 How many hours a week do you use a } \\
\text { computer/tablet/smartphone? }\end{array}$ & 0.152 & 0.153 & 0.324 & $.528^{*}$ & 0.072 & \\
\hline 7 & T1 Acceptance - Needs Satisfaction & 0.199 & 0.332 & 0.470 & -0.082 & $.503^{*}$ & 0.474 \\
\hline 8 & T2 Acceptance - Needs Satisfaction & -0.011 & 0.314 & $\overline{-}-118$ & 0.028 & $-\overline{0}-258$ & 0.289 \\
\hline 9 & T1 Acceptance - Public Acceptance & 0.157 & 0.141 & 0.287 & 0.249 & 0.011 & 0.216 \\
\hline 10 & T2 Acceptance - Public Acceptance & -0.137 & $\overline{-}-157$ & $\overline{-}-280$ & 0.035 & $-\overline{0}-268$ & 0.003 \\
\hline 11 & T1 Acceptance - Perceived Usability & -0.379 & 0.088 & $-\bar{c}-056$ & -0.208 & $-\overline{0}-028$ & $\overline{-}-030$ \\
\hline 12 & T2 Acceptance - Perceived Usability & -0.058 & 0.233 & $-\overline{0}-187$ & 0.018 & $-\overline{0}-167$ & 0.187 \\
\hline 13 & T1 Acceptance Support Availability & -0.264 & $\overline{-}-018$ & $\overline{-}-079$ & 0.240 & $\overline{-}-426$ & 0.172 \\
\hline 14 & T2 Acceptance Support Availability & 0.103 & 0.212 & $\overline{-}-068$ & 0.148 & $\overline{-}-200$ & $\overline{-}-080$ \\
\hline 15 & T1 Acceptance Use Intention & 0.326 & $.536^{*}$ & 0.393 & -0.193 & $.734^{* *}$ & 0.074 \\
\hline 16 & T2 Acceptance Use Intention & 0.012 & 0.299 & $-\overline{0}-207$ & 0.142 & $\overline{0}-449$ & 0.200 \\
\hline
\end{tabular}

It seems that greater experience and use of is associated with greater needs satisfaction and intention to use technology. This is consistent with the TAM, which suggests perceived usefulness along with ease of use is a primary determinant of attitudes toward technology and eventual technology acceptance (see Scherer, Siddiq \& Tondeur, 2019).

Table 6: Is there a relationship between participants' attitude towards technology and their acceptance of technology?

\begin{tabular}{|l|l|l|l|l|l|l|l|}
\hline $\mathbf{1}$ & T1PositiveAttitude & $\mathbf{1}$ & $\mathbf{2}$ & $\mathbf{3}$ & $\mathbf{4}$ & $\mathbf{5}$ & $\mathbf{6}$ \\
\hline
\end{tabular}




\begin{tabular}{|l|l|l|l|l|l|l|l|}
\hline $\mathbf{2}$ & T2PositiveAttitude & 0.028 & & & & & \\
\hline $\mathbf{3}$ & T1NegativeAttitude & 0.169 & -0.048 & & & & \\
\hline $\mathbf{4}$ & T2NegativeAttitude & 0.018 & -0.442 & -0.042 & & & \\
\hline $\mathbf{5}$ & T1AnxietyDependence & $.606^{*}$ & -0.132 & -0.047 & 0.305 & & \\
\hline $\mathbf{6}$ & T2AnxietyDependence & -0.075 & 0.492 & 0.157 & 0.126 & 0.201 & \\
\hline $\mathbf{7}$ & T1Acceptance_needssatisfaction & $.637^{* *}$ & -0.052 & -0.054 & 0.248 & $.753^{* *}$ & -0.057 \\
\hline $\mathbf{8}$ & T2Acceptance_needssatisfaction & -0.035 & $.761^{* *}$ & -0.255 & 0.002 & 0.001 & 0.488 \\
\hline $\mathbf{9}$ & T1Acceptance_publicacceptance & 0.396 & -0.086 & -0.006 & 0.101 & $.760^{* *}$ & 0.276 \\
\hline $\mathbf{1 0}$ & T2Acceptance_publicacceptance & -0.330 & $.668^{* *}$ & -0.465 & -0.030 & -0.306 & 0.267 \\
\hline $\mathbf{1 1}$ & T1Acceptance_perceivedUsability & -0.110 & 0.149 & -0.181 & -0.268 & 0.108 & 0.008 \\
\hline $\mathbf{1 2}$ & T2Acceptance_perceivedUsability & 0.021 & $.712^{* *}$ & -0.194 & 0.098 & -0.010 & $.524^{*}$ \\
\hline $\mathbf{1 3}$ & T1Acceptance_SupportAvailability & -0.079 & 0.054 & 0.119 & -0.030 & 0.186 & 0.409 \\
\hline $\mathbf{1 4}$ & T2Acceptance_SupportAvailability & -0.189 & 0.176 & -0.151 & 0.172 & -0.035 & 0.195 \\
\hline $\mathbf{1 5}$ & T1Acceptance_UseIntention & $.599^{*}$ & -0.201 & 0.364 & 0.168 & 0.464 & -0.148 \\
\hline $\mathbf{1 6}$ & T2Acceptance_UseIntention & 0.104 & $.695^{* *}$ & 0.120 & -0.299 & 0.167 & $.619^{*}$ \\
\hline
\end{tabular}

The finding of positive attitude being associated with several aspects of technology acceptance is consistent with the literature and the TAM model (see Scherer, Siddiq \& Tondeur, 2019). Furthermore, the relationship evidenced between anxiety dependence and a number of aspects of acceptance of technology suggests the more positive an individual is toward technology, and the more dependent they are on it, the more likely he or she will perceive it as important, useful and intend to use it.

Did participants' usage, attitudes and acceptance of technology improve following a move towards technology-based work practices?

Most participants (79\% using technology more than once a day) reported high levels of use at baseline and this figure was not significantly higher (81\% using technology more than once a day) at follow-up. There was no significant difference in self-reported positive attitude toward technology, or negative attitude toward technology between pre and post implementation of the new system $(p<.05)$. However, a statistically significant difference in anxiety dependence was found between pre $(\mathrm{M}=2.4, \mathrm{SD}=.92)$ and post intervention $(\mathrm{M}=3, \mathrm{SD}=.90) ; \mathrm{Z}=-2.108, \mathrm{p}$ $=.035)$. This suggests that following the implementation of the technology system, Home Visitors became more anxious about not having access to technology. Home Visitors report anxiety about failing to check in, not having access to the internet or not having access to their smartphone, which was significantly greater at follow-up in comparison with baseline levels.

Overall participants' levels of acceptance of technology increased from a mean score of 4.85 at baseline to 5.03 at follow-up. However, there was no significant differences in self-reported acceptance in terms of needs satisfaction, public acceptance, perceived usability, support availability or use intention between pre and post implementation of the new system $(p<.05)$ 


\section{Conclusion}

Overall the findings from the current study provide some support for the TAM with evidence of greater use and experience of technology at baseline influencing an individual's acceptance of technology (needs satisfaction and use intention) and shaping their attitude (positive attitude and anxiety dependence) towards technology. In including the construct of attitude, through reverting to the earlier models of TAM, the study provided support for the suggestion that attitude should be recognised as an important element of behaviour change (Guo \& Zhou, 2016). In the implementation of technology-based work practices, it is important for organisations to recognise the individuality of each person's experience, usage, attitude and acceptance of technology, and consider how this might affect the transition.

The finding of a relationship between participants' use of technology and their levels of anxiety dependence, along with evidence of anxiety dependence becoming more pronounced with the change in work practices, should also be considered. While these findings may indicate a positive change in participants' recognition of the importance of technology, they may also have negative connotations with the potential for participants to feel the need to access technology outside of work hours, due to it becoming a performance criterion. This is particularly supported by the finding that great use of technology at baseline is associated with less anxiety dependence following implementation. It could be suggested that individuals who have greater use of technology for personal use prior to the implementation of technology mediated work practices, are less likely to associate technology use primarily with work based performance criteria, therefore are less likely to feel anxious about accessing it.

In considering these findings, it is important to acknowledge that, as with every study, there are several limitations that should be noted. Primarily the small sample size employed reduces the power of the statistical analysis used. The initial challenges of introducing a new technology system, the timeframe of the collection of baseline data, the cross-sectional nature of the study design, the use of a convenience rather and the reliance on self-report measures should be considered. Furthermore, there are limitations with the measure of attitudes and usage used which were focused on general technology rather than the specific form introduced. Finally, given that all the home visitors are female, the generalisation of the findings is limited. However, despite these limitations, the current study presents some interesting findings that require consideration by organisations in the move towards technology-based work practices. 


\section{References}

Bautista, J.R., Rosenthal, S., Lin, T.T.C., \& Theng, Y.L. (2018) Predictors and outcomes of nurses' use of smartphones for work purposes. Computers in Human Behavior, 84, 360-374. doi.org/10.1016/j.chb.2018.03.008

Cheever, N.A., Rosen, L.D., Carrier, L.M., \& Chavez, A. (2014). Out of sight is not out of mind: the impact of restricting wireless mobile device use on anxiety levels among low, moderate and high users. Computers in Human Behaviour, 37, 290-297. doi.org/10.1016/j.chb.2014.05.002

Davis, F. D. (1989), Perceived usefulness, perceived ease of use, and user acceptance of information technology. MIS Quarterly, 13 (3): 319-340. doi/org/10.2307/249008

Guo, B., \& Zhou, S. (2016). Re-examining the role of attitude in information system acceptance: a model from the satisfaction-dissatisfaction perspective. Enterprise Information Systems, 10 (4), 444-466. doi.org/10.1080/17517575.2015.1011070

Hoeven, C.L.T., van Zoonen. W. \& Fonner, K.L. (2016) The practical paradox of technology: The influence of communication technology use on employee burnout and engagement, Communication Monographs, 83:2, 239-263, doi : 0.1080/03637751.2015.1133920

Lee, C.C., Czaja, S. J., Moxley, J.H., Sharit, J., Boot, W.R., Charness, N. \& Rogers, W.A. (2018). Attitudes Toward Computers Across Adulthood From 1994 to 2013, Gerontologist, 59(1), 22-33. doi: 10.1093/geront/gny081

Marston, H.R., Kroll, M., Fink, D., de Rosario, H., \& Gschwind, Y.J. (2016). Technology use, adoption and behavior in older adults: Results from the iStoppFalls project. Educational Gerontology, 42(6), 371-387. doi.org/10.1080/03601277.2015.1125178

Rosen, L.D., Whaling, K., Carrier, L.M., Cheever, N.A., \& Rokkum, J. (2013). The media and technology usage and attitudes scale: An empirical investigation. Computers in Human Behavior, 29(6), 2501-2511. doi.org/10.1016/j.chb.2013.06.006

Scherer, R., Siddiq, F., \& Tondeur, J. (2019). The technology acceptance model (TAM): A meta-analytic structural equation modelling approach to explaining teachers' adoption of digital technology in education, Computers \& Education, 128, 13-35. doi.org/10.1016/j.compedu.2018.09.009.

Share, M., Doyle, E., Callahan, A., Greene, S., Wachtler, M., \& Boyd, E. (2011). Baseline Evaluation of the Dublin Docklands Parent Child Home Programme. Project Report. National College of Ireland, Dublin.

Taherdoost, H. (2018). A review of technology acceptance and adoption models and theories. Procedia Manufacturing, 22, 960-967. doi.org/10.1016/j.promfg.2018.03.137

Wang, L., Rau, P.P. \& Salvendy, G. (2011). Older Adults' Acceptance of Information Technology. Educational Gerontology, 37(12). doi.org/ 10.1080/03601277.2010.500588 


\section{Appendix 1: Home Visitors' Usage Attitudes and Acceptance Towards Technology}

1. Do you own a computer/tablet/smartphone?

$\square$ Yes

$\square$ No

2. Do you have access to a computer/tablet/smartphone?

$\square$ Yes

$\square$ No

3. Have you ever used a computer/tablet/smartphone?

$\square$ Yes

$\square$ No

*If you answered NO to Q3, then please skip Q4-7

4. How long have you used a computer/tablet/smartphone?

$\square$ More than 1 year

$\square$ More than 6 months

$\square$ More than 3 months

$\square$ More than 2 months

$\square$ More than 1 month

$\square 1$ month or less

5. How frequently do you use a computer/tablet/smartphone?

$\square$ More than once a day

$\square$ About once a day

$\square$ More than once a week

$\square$ More than once a month

$\square$ Less than once a month

$\square$ I normally do not use a computer/tablet/smartphone

6. How many hours a week do you use a computer/tablet/smartphone?

$\square 0$ - 1 hours

$\square$ Less than 5 hours

$\square$ 6-10 hours

$\square 10+$ hours

7. What do you use a computer/tablet/smartphone for? (please tick all that apply)

$\square$ Word processing

$\square$ Database/Spreadsheets

$\square$ Drawing

$\square$ Internet (checking facts)

$\square$ Email

$\square$ Internet (social networking, eg. Facebook)

$\square$ Playing games

$\square$ Internet (banking)

$\square$ Internet (purchasing)

$\square$ Other 
8. Please rate the extent to which you agree or disagree with the following statements

\begin{tabular}{|c|c|c|c|c|c|}
\hline & $\begin{array}{l}\text { Strongly } \\
\text { disagree }\end{array}$ & Disagree & $\begin{array}{l}\text { Neither } \\
\text { agree nor } \\
\text { disagree }\end{array}$ & Agree & $\begin{array}{l}\text { Strongly } \\
\text { agree }\end{array}$ \\
\hline $\begin{array}{l}\text { I feel it is important to be able to find any info } \\
\text { want online }\end{array}$ & & & & & \\
\hline $\begin{array}{l}\text { I feel it is important to be able to access the In } \\
\text { want }\end{array}$ & & & & & \\
\hline $\begin{array}{l}\text { I think it is important to keep up with the late } \\
\text { technology }\end{array}$ & & & & & \\
\hline I get anxious when I don't have my cell phone & & & & & \\
\hline I get anxious when I don't have the Internet a & & & & & \\
\hline I am dependent on my technology & & & & & \\
\hline Technology will provide solutions to many of & & & & & \\
\hline With technology anything is possible & & & & & \\
\hline I feel that I get more accomplished because of & & & & & \\
\hline New technology makes people waste too muc & & & & & \\
\hline New technology makes life more complicated & & & & & \\
\hline New technology makes people more isolated & & & & & \\
\hline
\end{tabular}

9. Please rate the extent to which you agree or disagree with the following statements

\begin{tabular}{|l|l|l|l|l|l|l|l|}
\hline & $\begin{array}{l}\text { Strongly } \\
\text { disagree }\end{array}$ & Disagree & $\begin{array}{l}\text { Slightly } \\
\text { disagree }\end{array}$ & $\begin{array}{l}\text { Neither } \\
\text { agree nor } \\
\text { disagree }\end{array}$ & $\begin{array}{l}\text { Slightly } \\
\text { agree }\end{array}$ & $\begin{array}{l}\text { Agree } \\
\text { Strongly } \\
\text { agree }\end{array}$ \\
\hline Using information technology is enjoyable & & & & & & & \\
\hline $\begin{array}{l}\text { Information technology provides more channels to } \\
\text { contact other people, e.g., family, friends }\end{array}$ & & & & & & & \\
\hline I use information technology to get information & & & & & & & \\
\hline $\begin{array}{l}\text { Information technology makes my life more } \\
\text { convenient and more comfortable }\end{array}$ & & & & & & & \\
\hline $\begin{array}{l}\text { Information technology makes my life more } \\
\text { efficient }\end{array}$ & & & & & & & \\
\hline
\end{tabular}




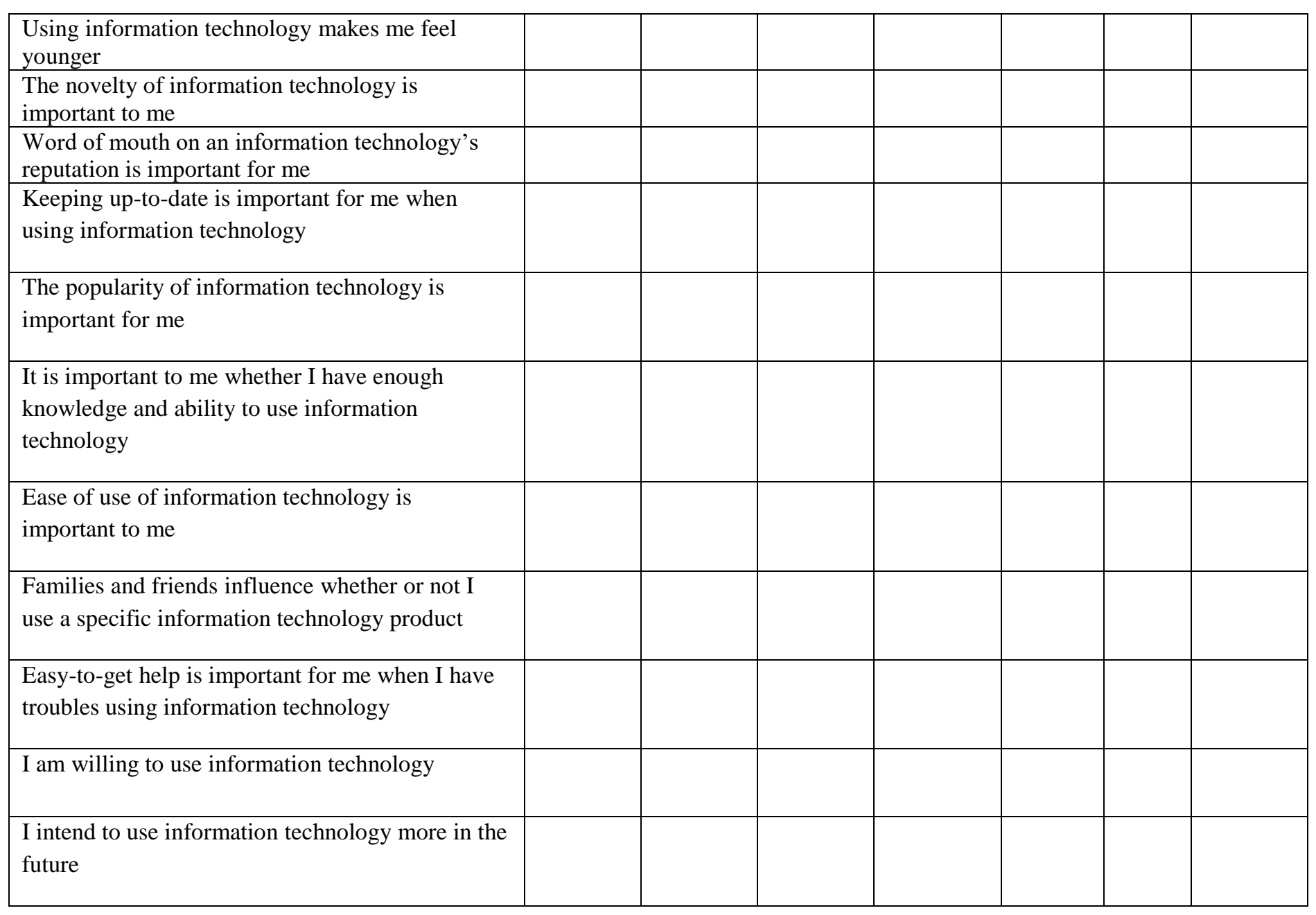

